\title{
Clostridium welchii Iota Toxin: Its Activation by Trypsin
}

\author{
BY HELEN E. ROSS, MARIAN E. WARREN AND JOAN M. BARNES \\ The Wellcome Physiological Research Laboratories, Beckenham, Kent
}

SUMMARY : The isolation, from sheep, of strains of the Bosworth type of Clostridium welchii is recorded; it is proposed to designate this type as $\mathrm{Cl}$. welchii type $\mathrm{E}$.

The toxicity of culture filtrates of $\mathrm{Cl}$. welchii type $\mathrm{E}$ after short growth periods is increased by treatment with crude trypsin preparations; no such increase can be demonstrated when the filtrates are from growths older than 5-7 hr. The toxin which is activated in these filtrates is the toxin iota. It appears that $\mathrm{Cl}$. welchii type E strains elaborate prototoxin convertible by enzymes into iota toxin proper.

In 1943 Bosworth described a type of Clostridium welchii differing in toxigenicity from the four types A, B, C and D of Wilsdon's (1931) classification. It had been isolated from the intestine of a calf being examined for evidence of enterotoxaemia, and was characterized by the elaboration of a toxin which he designated iota $(\iota)$. Subsequently we examined material from many cases of suspected enterotoxaemia in cattle and sheep, but it was not until 1944 that we isolated an iota-producing strain from the intestine of a lamb. Later in the same year iota toxin was identified in the bowel contents of three lambs, but, in spite of repeated attempts, no strains were isolated. In the spring of 1947, while examining a series of one hundred swab cultures taken from the udders of ewes on a farm infected with lamb dysentery, we identified iota toxin in forty of the mixed cultures from the swabs and isolated iota-producing strains from seven. These strains were tested by qualitative methods for the production of specific toxins and each was found to elaborate $C l$. welchii $\alpha$ and $\theta$ toxins in addition to iota toxin. Each resembled $\mathrm{Cl}$. welchii in morphology, cultural characters and staining reactions. They produced acid and gas in glucose, lactose, maltose, sucrose and glycerol, but only gas in inulin, mannitol and salicin. Bosworth included salicin among the sugars fermented by his strain; but this strain in our hands, when tested concurrently with the other strains, did not produce acid in this sugar. All the strains gave the typical $\mathrm{Cl}$. welchii stormy fermentation reaction in litmus milk, and liquefied gelatine. When grown on the surface of Dorset egg medium and on coagulated serum, each strain produced a slight softening and pitting of the surface. The indole reaction was negative. As the strains thus resemble Bosworth's in all respects, we consider that they belong to his new type which, with his consent, we propose to designate type $\mathbf{E}$.

In the course of testing these strains it was found by one of us (J.M.B.) that occasional filtrates of $5 \mathrm{hr}$. growths in a meat broth medium were non-toxic for mice when injected intravenously. When, however, the filtrates were treated with trypsin before injection they became toxic and, by antitoxin neutralization tests, were found to contain iota toxin. Other filtrates of similar growths contained only $\alpha$ toxin before trypsin treatment; after treatment the $\alpha$ toxin had disappeared and iota toxin was identified in the filtrates. 
This suggested that iota toxin, like $C l$. welchii $\epsilon$ toxin, might be produced initially as a non-toxic precursor or prototoxin (Turner \& Rodwell, 1943) convertible by enzyme action into a toxic form. Bosworth investigated the possibility that some such conversion might occur but found no increase in the toxicity of his filtrates after exposure to trypsin. These, however, in contrast to ours, were prepared from $18 \mathrm{hr}$. growths, and it seemed to us that at this time conversion from the non-toxic to the toxic form might have been completed. We therefore devised the following experiments to study the effect of trypsin on iota toxin.

\section{MATERIAL AND METHODS}

Filtrates were prepared from cultures of $\mathrm{Cl}$. welchii type $\mathbf{E}$ after different periods of growth and examined for the amount of iota toxin before and after treatment with trypsin.

The preparation of filtrates

Strains. Four of the nine available strains were selected: CN 1241, Bosworth's strains; CN 1493, isolated from the intestine of a 6 months old lamb; CN 1870 and $\mathrm{CN} 1993$, both isolated from swab cultures taken from the surface of ewes' udders.

Medium. Horse muscle infusion broth plus $1 \%$ by volume of papain digest of horse muscle (T.N $\mathbf{0 . 3} \%$ ), plus $\mathbf{3 0} \%(\mathrm{v} / \mathrm{v})$ cooked meat particles. Volumes of 4 l. were used, steamed for $1 \mathrm{hr}$. at $100^{\circ}$, cooled to $37^{\circ}$ and inoculated with $50 \mathrm{ml}$. of an overnight growth of seed culture in the same medium. Incubation was at $37^{\circ}$.

Sampling. Samples $(100 \mathrm{ml}$.) were withdrawn by pipette during growth at 2, 3, 4, 5 and $7 \mathrm{hr}$. after inoculation. At $2 \mathrm{hr}$. growth, though slight, was always evident; the peak of growth, as judged by turbidity, a lightening in colour and gas evolution, was usually reached at about $5 \mathrm{hr}$.

Filtration. Samples were filtered immediately after collection through sterilizing filter-pads (Ford S.B. grade Sterimats).

Treatment with trypsin. A crude preparation of pig pancreas was used. It was kept at $c .4^{\circ}$ at $\mathrm{pH} 4.0$ and filtered through paper as required. The filtrate from the crude pancreas preparation was added $(5 \% \mathrm{v} / \mathrm{v})$ to culture filtrates without adjustment of the $\mathrm{pH}$, and the mixtures incubated for one hour at $37^{\circ}$. The necessary dilutions were then made in saline and injected.

\section{Measurement of toxicity}

The toxicity of culture filtrates was measured by estimating the LD 50 for mice, and the minimal necrotizing dose (M.N.D.) for guinea-pigs. The LD 50 is defined as the smallest dose which, when injected intravenously into mice of 20-22 g. weight, kills $50 \%$ of the animals within $72 \mathrm{hr}$. The M.N.D. is the smallest dose producing a characteristic necrotic reaction when injected intracutaneously into guinea-pigs. Culture filtrates were diluted in saline and the volume of each dose under test was adjusted with saline to $0.5 \mathrm{ml}$. for the LD 50 and $0.2 \mathrm{ml}$. for the M.N.D. test. 


\section{Helen E. Ross, Marian E. Warren and Joan M. Barnes}

As $C l$. welchii $\alpha$ toxin was almost certain to be present in filtrates from such short growths, and as by its lethal and necrotizing action it would interfere with the in vivo tests for iota toxin, an excess of $\alpha$ antitoxin free from iota antitoxin was added to all dilutions.

In estimating both the $\mathrm{LD} 50$ and the M.N.D. the dose in initial tests varied by 50 or $20 \%$. In confirmatory tests on the LD 50 they varied by $10 \%$; two or three LD 50 determinations were carried out on this range using two mice to each dose. The M.N.D. determination could not be made on a range closer than $20 \%$.

The $L+$ dose in mice. The $\mathrm{L}+$ in mice is defined as the smallest dose of toxin which, when mixed with one unit of antitoxin, kills within $72 \mathrm{hr} .50 \%$ of the animals injected intravenously. The unit of antitoxin was that devised by Mr A. T. Glenny in these Laboratories in 1943, and is contained in $0.004 \mathrm{ml}$. of a provisional standard serum prepared in a horse by the injection of filtrates of $\mathrm{Cl}$. welchii type E. Serial dilutions of culture filtrate in $\mathbf{1 . 0} \mathrm{ml}$. were mixed with one unit of iota antitoxin in $1.0 \mathrm{ml}$. saline, and kept at room temperature for $30 \mathrm{~min}$; $0.5 \mathrm{ml}$. of each mixture was then injected into each of two mice. As in the LD 50 tests the dilutions varied initially by 20-50\%, and in confirmatory tests by $10 \%$. The $\mathbf{L}+$ dose was also determined with an excess of epsilon antitoxin (30 units) included in each iota toxin-antitoxin mixture.

\section{RESULTS}

Iota toxin was not demonstrable in any of the four untreated culture filtrates from $2 \mathrm{hr}$. growths; after treatment with trypsin it was demonstrable in two (Table 1).

Table 1. The effect of trypsin on the LD 50 (mouse) of iota toxin in culture filtrates after different periods of growth

$-\mathbf{T}$ and $+\mathbf{T}=$ filtrate before and after treatment with trypsin.

Culture filtrates from

\begin{tabular}{|c|c|c|c|c|c|c|c|c|}
\hline \multirow{3}{*}{$\begin{array}{l}\text { Period of } \\
\text { growth } \\
\text { (hr.) }\end{array}$} & \multicolumn{2}{|c|}{ CN 1241} & \multicolumn{2}{|c|}{ CN 1870} & \multicolumn{2}{|c|}{ CN 1493} & \multicolumn{2}{|c|}{ CN 1993} \\
\hline & $-\mathrm{T}$ & $+\mathrm{T}^{\mathrm{v}}$ & $-\mathbf{T}$ & $+\mathbf{T}$ & $-\mathrm{T}$ & $+\mathrm{T}$ & $-\mathrm{T}$ & $+\mathbf{T}$ \\
\hline & \multicolumn{8}{|c|}{ LD 50 doses (ml.) } \\
\hline 2 & $>0.50$ & $>0.50$ & $>0.50$ & $>0.50$ & $>0.50$ & 0.09 & $>0.50$ & $0 \cdot 43$ \\
\hline 3 & $>0.50$ & 0.09 & $>0.50$ & 0.15 & 0.065 & 0.024 & $0 \cdot 16$ & 0.06 \\
\hline 4 & $0 \cdot 21$ & 0.036 & $0 \cdot 30$ & $0 \cdot 10$ & - & - & - & $\ldots$ \\
\hline 5 & $0 \cdot 12$ & 0.033 & $0 \cdot 20$ & 0.06 & $0 \cdot 036$ & 0.018 & 0.035 & $0 \cdot 027$ \\
\hline 7 & 0.05 & 0.045 & $0 \cdot 15$ & 0.08 & 0.033 & $0 \cdot 027$ & $0 \cdot 026$ & $0 \cdot 024$ \\
\hline
\end{tabular}

The LD 50 of two treated filtrates of $4 \mathrm{hr}$. growths, and of four filtrates of $5 \mathrm{hr}$. growths were less than those of the same filtrates before treatment with trypsin; the LD 50 of three out of four filtrates of $\mathbf{7 ~ h r}$. growths did not show any significant change after treatment with trypsin.

Similar decreases in the M.N.D. after trypsin treatment of filtrates were 
shown in the guinea-pig intracutaneous test (Table 2). The maximum dose $(0.2 \mathrm{ml}$.) of the untreated filtrates of $2 \mathrm{hr}$. growths produced no reaction, but after treatment, $0.011 \mathrm{ml}$. of one filtrate and $0.04 \mathrm{ml}$. of another produced reactions characteristic of iota toxin. The M.N.D. of $3 \mathrm{hr}$. filtrates decreased to roughly one-third of their previous values after treatment, but the doses of 5 and $7 \mathrm{hr}$. filtrates were not significantly affected. Characteristic reactions did not develop as a rule until $48 \mathrm{hr}$. after injection. At this time the reactions consisted of flat, roughly circular areas of greyish white necrosis vaguely outlined with purple; occasionally the reactions consisted of irregular shaped areas of purplish haemorrhage without necrosis.

Table 2. The effect of trypsin on the minimal necrotizing dose (M.N.D.) of iota toxin in culture filtrates after various periods of growth, measured in guinea-pig skin

$-T$ and $+T=$ filtrate before and after treatment with trypsin.

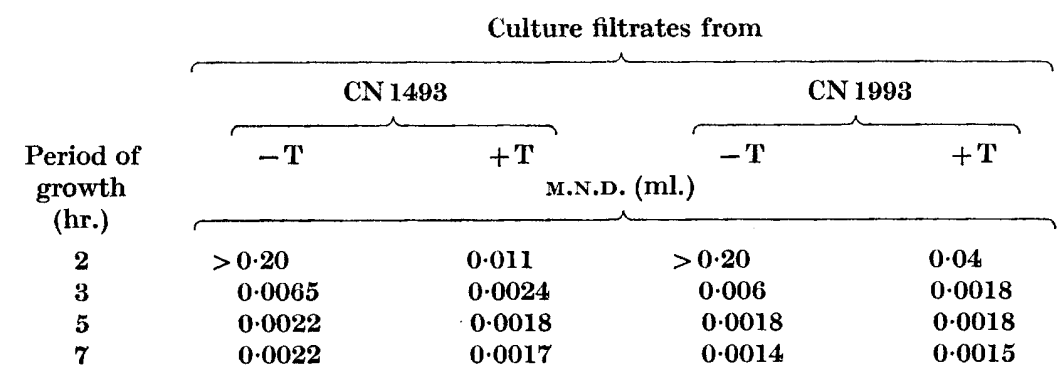

The $\mathbf{L}+$ dose was also affected by treatment of the filtrates with trypsin although, like the M.N.D., only with filtrates from 2 and $3 \mathrm{hr}$. growths. The $\mathrm{L}+$ for the $2 \mathrm{hr}$. untreated filtrates could not be determined because toxin could not be demonstrated in the maximum amount of filtrate that it was practicable to inject. After treatment with trypsin these filtrates had an $\mathbf{L}+$ value of $1.2 \mathrm{ml}$. (Table 3 ).

Table 3. The effect of trypsin on the $L+$ dose (mouse) of iota toxin in culture filtrates after various periods of growth

$-\mathrm{T}$ and $+\mathrm{T}=$ filtrate before and after treatment with trypsin. $\mathbf{N M}=\mathbf{L}+$ not measurable because filtrate insufficiently toxic.

\begin{tabular}{|c|c|c|c|c|}
\hline \multirow{4}{*}{$\begin{array}{c}\text { Period of } \\
\text { growth } \\
\text { (hr.) }\end{array}$} & \multicolumn{4}{|c|}{ Culture filtrates from } \\
\hline & \multicolumn{2}{|c|}{ CN 1493} & \multicolumn{2}{|c|}{ CN 1993} \\
\hline & $-T$ & $+\mathbf{T}$ & $-\mathbf{T}$ & $+\mathrm{T}$ \\
\hline & \multicolumn{4}{|c|}{ Volume $(\mathrm{ml}.) \equiv 1$ iota unit } \\
\hline 2 & NM & $1 \cdot 2$ & NM & NM \\
\hline 3 & 0.50 & $0 \cdot 33$ & $\mathbf{1} \cdot \mathbf{2 4}$ & $0 \cdot 53$ \\
\hline 5 & $0 \cdot 38$ & $0 \cdot 33$ & $0 \cdot 36$ & $0 \cdot 38$ \\
\hline 7 & $0 \cdot 34$ & $0 \cdot 30$ & $0 \cdot 39$ & $0 \cdot 40$ \\
\hline
\end{tabular}




\section{DISCUSSION}

Our results show that the toxicity of $\mathrm{Cl}$. welchii type $\mathrm{E}$ filtrates is increased by treatment with crude trypsin preparations. As there is evidence that $\alpha$ and $\theta$ toxins are destroyed by this treatment, and the treated filtrates were neutralized by iota antisera not containing any $\epsilon$ antibody, and not by $\epsilon$ antisera containing no iota antibody, we conclude that the increased toxicity is due to iota toxin.

The increases of toxicity were not so great as those shown by $\epsilon$ toxin (Batty \& Glenny, 1947) but were sufficient to show that iota toxin, like $\epsilon$ toxin, has a non-toxic precursor from which it is formed by the action of crude trypsin. We therefore postulate that type $\mathbf{E}$ strains produce, in addition to $\alpha$ and $\theta$ toxins, an iota prototoxin convertible by enzyme action into iota toxin proper. Judging by the results with $\epsilon$ toxin reported by Batty \& Glenny, the changes in the iota $\mathbf{L}+$ value after trypsin treatment were far greater than would have been expected from the relatively small changes in the LD 50 dose.

The time at which the maximum increase in toxicity occurred could not be determined because the culture filtrates after the shortest growth periods teșted were non-toxic, but it evidently must have been within the first $3 \mathrm{hr}$. after inoculation. It may be assumed that complete transformation from the suggested precursor had been brought about by the organism's own enzyme systems after $7 \mathrm{hr}$., as trypsin treatment then had no effect.

We wish to thank Prof. T. J. Bosworth for sending us his strain, and Dr C. L. Oakley for the supply of antitoxin and for much helpful advice and criticism.

\section{REFERENCES}

Batty, I. \& Glenny, A. T. (1947). Titration of Cl. welchii epsilon toxins and antitoxins. Brit. J. exp. Path. 27, 110.

Bosworth, T. J. (1943). On a new type of toxin produced by Cl. welchii. J. comp. Path. 53, no. 3, 245.

Turner, A. W. \& Rodwell, A. W. (1943). The Epsilon toxin of Cl. zelchii type D. 1. Proteolytic conversion of $\epsilon$ prototoxin into $\epsilon$ toxin by trypsin and other proteases. Aust. J. exp. Biol. med. Sci. 27, 17.

Wilsdon, A. J. (1931). Observations on the classification of B. relchii. Rep. Dir. Inst. Anim. Path. Camb. 2, 53. 